\title{
RESEÑAS DE FONOGRAMAS
}

A lo Humano y lo Divino. Alfonso Ureta (vozy guitarrón chileno), [Publicación digital] Pirque: producción independiente, 2020.

A lo Humano y lo Divino es el primer disco en solitario de Alfonso Ureta (n. 1986) compositor, cantante y docente, experto en folclor chileno, líder del grupo Los del Maipo, galardonado por Altazor, Pulsar, y Margot Loyola: Premio a la Música de Raíz. El disco fue realizado en tiempos de cuarentena, y es el fruto de quince años de trayectoria del autor, cultivando el arte de la décima y el guitarrón. El disco, que fue grabado, mezclado y masterizado

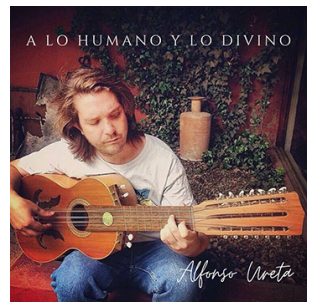
por el propio Alfonso en su casa en Pirque, se nutre de la escuela pircana del Canto a lo Poeta, no solamente por ser gestado en esta comuna de la provincia de Cordillera, sino también porque el autor es discípulo de Alfonso Rubio, maestro guitarronero de la zona. Pirque tiene la fama de ser uno de los centros neurálgicos del guitarrón en Chile, por la existencia de destacados cultores en diversos períodos, como Isaías Angulo, Santos Rubio y Juan Domingo Pérez, por nombrar solo algunos. A su vez, la comuna ha impulsado un encuentro anual de guitarroneros desde 2002 hasta la actualidad.

A lo Humano y lo Divino tiene el propósito de exhibir un amplio registro de toquíos del guitarrón, con composiciones poéticas de Alfonso Ureta. Si bien la inspiración y matriz proviene del Canto a lo Poeta pircano, el disco exhibe toquíos inspirados en diversas localidades de la zona central de Chile. Según explica el autor, el guitarrón se utiliza para acompañar el Canto a lo Poeta, tradición compuesta por tres vertientes: el canto a lo humano, el canto a lo divino y la paya, incluyéndose en el disco a las primeras dos. El canto a lo humano incluye temáticas profanas del mundo campesino y temáticas políticas nacionales, mientras que el canto a lo divino incluye temáticas de contenido religioso y bíblico. Las piezas son:

1. "Por Presentación - La Común" (2'14")

2. "Introducción - Rosa Romero" (2'3")

3. "Por la Guitarra Grande - La con Ay Sí" (2'31")

4. "Mi tierra tiene un encanto - La Españolita" (2'39")

5. "Por las Aves - La Pajarera" (3'5")

6. "Un árbol cuando es caduco" - (2'7")

7. "Mi caballo se ha perdido - La del Diablo" (1'36")

8. "Por el Nato Eloy - La Principalina" (2'30")

9. "Por Wallmapu - La Tres Fulminante" (2'21")

10. "Por 21 de Mayo - La Ladeá" (1'43")

11. "Por Fiestas Patrias - La del Medio" (2'1")

12. "Por Creación - La Fantástica" (1'53")

13. "Por el Diluvio - La Caña con Choclo" (2'10")

14. "Por David - La Aculeguana" (2'46")

15. "Por la Virgen - La Pircana" (2'44") 
16. "Por Nacimiento - La Mágica" (2’3")

17. "Por San Juan - La Dentradora" (1'54")

18. "Por Padecimiento - La Tarifeña" (3’)

19. "Por el Judío Errante - La Sí Ayayay" (1'49")

20. "Por Apocalipsis - Revelaciones de un Sueño" (1'54")

21. "Por Despedida - La Colchagüina" (2'4")

El disco se estructura en cuatro secciones. La primera sección es de introducción, la segunda de canto a lo humano, la tercera de canto a lo divino, y la cuarta de despedida. La primera y última sección son una adaptación de la modalidad de introducción y despedida que generalmente se realizan en las ruedas y ritos del Canto a lo Poeta. La sección de introducción incluye una canción de presentación del autor y otra acerca del motivo del disco. La sección a lo humano incluye nueve canciones: la primera alude al guitarrón, las siguientes cuatro a temáticas del mundo campesino, como la tierra, las aves, los árboles y los caballos. Mientras que las siguientes canciones describen temas profanos de corte político y conmemorativo, como son el Nato Eloy - un bandolero chileno retratado por el escritor chileno Carlos Droguett-, el Wallmapu -en alusión a la causa mapuche-, y celebraciones nacionales del 21 de mayo y las fiestas patrias. En la sección a lo divino, se abordan, primero, eventos y personajes del Antiguo Testamento como la Creación, el Diluvio y David; después, eventos y personajes del Nuevo Testamento como la Virgen, el Nacimiento de Jesús y san Juan.

Las veintiún canciones del disco están compuestas bajo un mismo formato: una introducción con solo de guitarrón, y un canto de un verso en décima. La duración de las canciones oscila entre el minuto y medio -la más breve- ("Mi caballo se ha perdido") y los tres minutos -la más extensa("Por las aves"). La brevedad de las canciones y la inclusión de solo un verso cantado, es un sello particular de la propuesta creativa de Alfonso, que contrasta, por ejemplo, con los versos largos de los discos de Manuel Sánchez, guitarronero especializado en el arte poética y de la paya. Así, A lo Humano y lo Divino cumple una función pedagógica al enseñar diversas entonaciones y formas de ejecutar el guitarrón y cantar las décimas, pudiendo complementarse con la información proporcionada por el autor en su sitio web personal ${ }^{1}$, que incluye una reseña del guitarrón. En esta, se explica el vínculo del guitarrón con la décima espinel, sus orígenes con la evangelización jesuita, y sus influencias remotas en el canto gregoriano, la armonía modal y el canto melismático. Además, se hace una breve referencia al trabajo de Violeta Parra y del investigador Juan Uribe Echeverría en el rescate y promoción del guitarrón.

El disco fue realizado con el apoyo de la Asociación Gremial Nacional de Trabajadores de la Poesía Popular, Poetas y Payadores de Chile, lo que da cuenta de la conexión del autor con el mundo del Canto a lo Poeta nacional. Combina elementos tradicionales e innovadores, ya que se nutre de la investigación de una tradición musical y poética local, utilizando formatos de alto alcance mediático para su difusión, como son las plataformas Spotify, Youtube y Portaldisc.com. En síntesis, A lo Humano y lo Divino es una contribución significativa al arte de la décima y el guitarrón en Chile, que promueve y entrega nuevos aires a una tradición que ha sido respetuosamente aprendida y difundida por el autor.

$$
\begin{array}{r}
\text { Ignacio Rivera Volosky } \\
\text { Department of Spanish, } \\
\text { Portuguese and Latin American Studies } \\
\text { King's College, Inglaterra } \\
\text { ignacioriveravolosky@gmail.com }
\end{array}
$$

1 http://www.alfonsouretam.com/ [acceso: 1 de diciembre de 2020]. 